\title{
Effect of Computer Aided Instruction on Students' Academic Achievement in Corporate Ethics at Tertiary Institutions Level in North Eastern Nigeria
}

\author{
*Dr Adamu Ibrahim ${ }^{1} \quad$ Bala Mohammed ${ }^{1} \quad$ Abdu Babaji $^{2}$ \\ 1.Department of Vocational and Technology Education, Faculty of Technology Education, Abubakar Tafawa \\ Balewa University, Bauchi, Nigeria \\ 2.Department of Business Education, Federal College of Education (Technical), Gombe, Gombe state, Nigeria
}

\begin{abstract}
This study investigated the effect of Computer Aided Instruction (CAI) on the achievement of students in corporate ethics at tertiary level institution. The study had four objectives, four research questions and four null hypotheses. Quasi-experimental design was used for the study. The population of the study was 202 students that offered corporate ethics 2017/2018 academic year in three universities offering Business Education in North-Eastern Nigeria. 136 students were used for study. Data were collecting using a multiple choice question. The instrument was validated by 4 experts in Vocational and Technical Education. In order to determine the reliability of the instrument, pilot test was conducted. The result gave reliability coefficient of 0.67 . The data for the questions were analyzed using mean and standard deviation to answer research questions while t-test was employed in testing the null hypotheses at the 0.05 level of significance. Results of the study revealed that students taught CAI package achieved better than those taught using the conventional lecture method. It therefore means that the use of CAI will help to improve the performance of students in corporate ethics. It was therefore recommended among other things that, business education lecturers should incorporate the use of CAI in teaching corporate ethics to students Keywords: Computer Aided Instruction. Academic Achievement, Corporate Ethics.
\end{abstract}

DOI: $10.7176 / \mathrm{JEP} / 10-29-07$

Publication date:October $31^{\text {st }} 2019$

\section{Introduction}

The ways things are done in home, work places and in schools are constantly changing all over the world. The uses of computers are definitely influencing lives, and can enhance the learning process in the schools. The recognition of the value of computers in the teaching -learning process in the contemporary world introduced computer education led to the Nigerian school curriculum (Achuonye, 2011). This in effect means that students can proceed at their own time, following a path through the curriculum suited for their interest and talent. According to Yusuf and Afolabi (2010), the use of Computer Aided Instruction Package (CAIP) as a supplement to conventional method produced higher achievements by the learners than using conventional method alone.

Many teaching methods have been used in the past for teaching corporate ethics at the universities level. These approaches include; lecture method, demonstration method, discussion methods which are expository in nature. Expository methods, according to Nwokenna (2010), consist of the presentation of concepts, facts and principles by the teacher while the students are merely asked to listen and take notes. These facts and principles are drawn from textbooks based on the stipulated contents and cognitive levels within the unit of instruction. The foregoing presents a picture of the use of poor teaching methods during corporative ethics instruction which according to Nwokenna (2010), may not improve the performance of students in their academic pursuit. The above scenario tends to suggest that the conventional teaching method used have accounted for the persistent low academic performance in business education by students. It then means that more efforts should be intensified in developing new teaching methods which may improve the student's academic performance in corporate ethics in higher institutions.

One of the recommended teaching approaches by the Federal Ministry of Education (2007), is the Computer Assisted Instruction (CAI). CAI refers to the use of computer as a tool in teaching and training. It includes drill and practice tutorials, simulations, instructional management, supplementary exercises, data base management, word processing and other types of computer applications. According to Okereke (2002), CAI may also refer to the stand alone computer learning activities in the computer lesson with reinforced materials introduced an taught by teachers. The students receive feedback from the computer and maintain some degree of control. CAI as a supplement to conventional teacher-directed instruction produces achievement effects superior to those obtained with the traditional approach alone (Akudolu, 2008). Examples of CAI applications include guided drill practice exercise, computer visualization of complex objects, and computer facilitated communication between students and teachers. The guided drills is a computer programme that poses questions to students, returning feedback and selects additional questions based on the student's responses. Recent guided drill system 
incorporate the principles of education in addition to subject matter knowledge into computer programme. Some of the CAI tools (such as word processors, spreadsheets and data base) connect, organize, analyze and transmit information. They also facilitate communication among students and instructor, and beyond the classroom to distant students, instructors and experts.

In spite of the fact that we are in Technological era which pave way for increased changes in the way and manner undergraduate student learn, yet the conventional method (lecture) dominate our classrooms/lecture halls. According to Neekpoa (2007) Nigeria is saddled with educational problem of great magnitude which the traditional methods of teaching and learning alone cannot solve. Orjika (2012) stress that the traditional approach of delivery of knowledge and skills through lecture must be improve or even abundant and replace with methodologies which allow students to learn needed skills in the context within which the skill are used in the real world. It is in light of the aforementioned reasons that the researcher felt the need to undertake this research work which seeks to determine the Effect of Computer Aided Instruction Package on Students' Academic Achievement in Corporate Ethics at Tertiary institution Level in North Eastern Nigeria. Specifically, the study intends to: (1) determine the difference between the pretest mean performances of students taught corporate ethics using CAI and those taught using lectures method; (2) ascertain the difference between the pretest and posttest mean performances of students taught corporate ethics using lectures method; (3) establish the difference between the pretest and posttest mean performances of students taught corporate ethics using CAI; and (4) determine the difference between the posttest mean performance of students taught corporate ethics using CAI

\section{Research Questions}

The study will provide answers to the following specific research questions:

1. What is the difference between the pretest mean performances of students taught corporate ethics using CAI and those taught using lectures method?

2. What is the difference between the pretest and posttest mean performance of students taught corporate ethics using lectures method?

3. What is the difference between the pretest and posttest mean performance of students taught corporate ethics using CAI?

4. What is the difference between the posttest mean performances of students taught corporate ethics using CAI?

\section{Research Hypotheses}

In line with research questions, the following null hypotheses are formulated

1. There is no significant difference between the pretest mean performances of students taught corporate ethics using CAI and those taught using lectures method

2. There is no significant difference between the pretest and posttest mean performances of students taught corporate ethics using lectures method.

3. There is no significant difference between the pretest and posttest mean performances of students taught corporate ethics using CAI.

4. There is no significant difference between the posttest mean performances of students taught corporate ethics using CAI.

\section{Methodology}

\section{Design of the Study}

The study was conducted using quasi-experimental design. The symbol below represented is presented in Table 1 . Table 1: Design of the study

\begin{tabular}{llll}
\hline Groups & Pre-test & Treatment & Post-test \\
\hline Experimental & $\mathrm{P}_{1}$ & CAI & $\mathrm{P}_{2}$ \\
Control & $\mathrm{P}_{3}$ & & $\mathrm{P}_{4}$ \\
\hline
\end{tabular}

\section{Population of the Study}

The population for this study comprises of 202 Business Education Students (Management Option) in the three Federal Universities in the North East, Nigeria.

\section{Sample and Sampling Techniques}

The researcher used simple random sampling technique and selected two Universities for the study. The two selected Institutions were University of Maiduguri UNIMAID and Modibbo Adama University of Technology MAUTECH Yola with the total population of 136. The institutions were assigned experimental and control group. Instrument for Data Collection

The instrument is Cooperate Ethics Achievement Test I (pre-test) and Cooperate Ethics Achievement Test II (post- 
test). The instrument contained 30 multiple choice items. The pre-test was used to determine the entry level of students. The pre-test was reshuffled and used as post-test. The instrument was adopted from the moderated pass question papers; hence the instrument was not subjected to validation.

\section{Reliability of the Instrument}

The split-half method was used in testing the objective questions for the reliability coefficient. The data collected from the pilot study were subjected to statistical analysis using the Spearman-Brown reliability coefficient was 0.77 while is positive and high, hence the instrument was adjudged reliable and stable.

\section{Method of Data Collection}

The experiment was commenced with the administration of pre-test on both the experimental and control groups. The exercise provided baseline data on students' achievement in corporate ethics before the treatment. After the pretest, a period of treatment on the use of CAIP adopted and modified by the researcher was giving the experimental group by the researcher/class teacher who is computer compliance. The package contains four weeks interactive tutorial lesson on the introduction of code ethics theory. The control group were taught the conventional plan on chalkboard using explanation and demonstration etc. as demanded. The treatment lasted for four weeks. The post-test was administered to all treatment groups immediately after the completion of the treatment.

\section{Method of Data Analysis}

The data was analyzed using statistical package (SPSS) version 22.0 the Mean and standard deviation reliability than other measures of control tendencies as the mean was used to interpret achievement, SD was employed as it is the stable measures of variability. While the null hypotheses were tested using t-test at 0.05 level of significance.

\section{Results}

\section{Research Question One:}

What is the difference between the pretest mean performances of students taught corporate ethics using CAI and those taught using lectures method?

The descriptive statistics used to answer research question one revealed the mean score of 21.29 with standard deviation of 4.17 for students taught corporate ethics using CAI. The mean of 22.49 with standard deviation of 3.28 was obtained for students in lectures method. The mean difference of 1.20 was not significant, therefore it was concluded that there was no difference between the pretest mean scores of student taught corporate ethics using CAI and those taught using lectures.

Table 2: Mean sores for answering research question one

\begin{tabular}{lllll}
\hline Teaching method & N & Mean & Std. dev & Mean diff \\
\hline Computer Aided Instruction & 73 & 21.29 & 4.17 & \multirow{2}{*}{1.20} \\
Lectures & 63 & 22.49 & 3.28 & \\
\hline
\end{tabular}

\section{Research Question Two}

What is the difference between the pretest and posttest mean performance of students taught corporate ethics using lectures method?

The pretest and posttest mean scores of students taught corporate ethics using lectures method stood at 22.49 and 23.45 with standard deviation of 3.28 and 4.02 respectively. The mean difference of 1.04 was not large, it was therefore concluded that no much difference exists in the pretest and posttest mean performance of students taught corporate ethics using lectures method.

Table 3: Mean sores for answering research question two

\begin{tabular}{lcccc}
\hline Lectures method & $\mathrm{N}$ & Mean & Std. dev & Mean difference \\
\hline Pretest & 63 & 22.49 & 3.28 & \multirow{2}{*}{1.04} \\
Posttest & 63 & 23.45 & 4.02 & \\
\hline
\end{tabular}

\section{Research Question Three}

What is the difference between the pretest and posttest mean performance of students taught corporate ethics using CAI?

The descriptive statistics used to determine the difference between the pretest and posttest mean performance of students taught corporate ethics using CAI is presented in Table 4. From the Table, the pretest mean score was 21.29 with standard deviation of 4.17 while the posttest mean score was 34.54 with standard deviation of 4.72 . The mean difference of 13.25 obtained was large, hence it was concluded that CAI instruction has positive effect on performance of students in business ethics.

Table 4: Mean sores for answering research question three 


\begin{tabular}{lllll}
\hline CAI & N & Mean & Std. dev & Mean difference \\
\hline Pretest & 73 & 21.29 & 4.17 & \multirow{2}{*}{13.25} \\
Posttest & 73 & 34.54 & 4.72 & \\
\hline
\end{tabular}

\section{Research Question Four}

What is the difference between the posttest mean achievement of students taught corporate ethics using CAI?

The result of performance of students taught corporate ethics using CAI revealed the mean score of 34.54 with standard deviation of 4.72. Students taught using lectures method had mean score of 23.45 with standard deviation of 4.02. The mean difference of 11.11 obtained was large, hence it was concluded that students taught corporate ethics using CAI performed significantly better than those taught using lectures method.

Table 5: Mean sores for answering research question four

\begin{tabular}{lcccc}
\hline Posttest & N & Mean & Std. dev & Mean difference \\
\hline Computer Aided Instruction & 73 & 34.54 & 4.72 & \multirow{2}{*}{11.11} \\
Lectures & 63 & 23.45 & 4.02 & \\
\hline
\end{tabular}

\section{Test of the Null Hypotheses}

\section{Hypothesis One}

There is no significant difference between the pretest mean performance of students taught corporate ethics using CAI and those taught using lectures method

The t-test analysis used to test null hypothesis one revealed the p-value of 0.23 which was greater than 0.05 level of significance. The results show that no significant difference exists between the mean score of the two groups of students. The null hypothesis was retained.

\section{Table 6:t-test analysis used to test null hypothesis one}

\begin{tabular}{lcccccc}
\hline Group & $\mathrm{N}$ & Mean & SD & Df & t-cal & P \\
\hline CAI & 73 & 21.29 & 4.17 & 134 & 1.84 & 0.23 \\
Lectures & 63 & 22.49 & 3.28 & & & \\
\hline
\end{tabular}

\section{Hypothesis Two}

There is no significant difference between the pretest and posttest mean performance of students taught corporate ethics using lectures method.

The result of null hypothesis two revealed the p-value was greater than the level of significant $(0.13>0.05)$, the results therefore shows that no significant difference exists between the pretest and posttest mean performance of students taught corporate ethics using lectures. The null hypothesis was retained.

Table 7:t-test analysis used to test null hypothesis two

\begin{tabular}{lcccccc}
\hline Lectures method & $\mathrm{N}$ & Mean & Std. dev & Df & t-cal & P \\
\hline Pretest & 63 & 22.49 & 3.28 & 124 & 1.62 & 0.13 \\
Posttest & 63 & 23.45 & 4.02 & & & \\
\hline
\end{tabular}

\section{Hypothesis Three}

There is no significant difference between the pretest and posttest mean performance of students taught corporate ethics using CAI.

The test of null three revealed the probability value less that the alpha value $(.001<0.05)$. The result of the analysis shows that there was significant difference between the pretest and posttest mean performance of students taught corporate ethics using CAI. The null hypothesis was rejected.

Table 8: t-test analysis used to test null hypothesis three

\begin{tabular}{lllllll}
\hline CAI & N & Mean & Std. dev & Df & t-cal & P \\
\hline Pretest & 73 & 21.29 & 4.17 & 144 & 1.99 & 0.001 \\
Posttest & 73 & 34.54 & 4.72 & & & \\
\hline
\end{tabular}

\section{Hypothesis Four}

There is no significant difference between the posttest mean performances of students taught corporate ethics using CAI.

The t-test analysis presented in Table 9 revealed the p-value of .000 which was less than the 0.05 level of significance. The results therefore shows no there was significant difference between the posttest mean performance of the two groups of students. The null hypothesis was rejected. 
Table 9:t-test analysis used to test null hypothesis four

\begin{tabular}{lcccccc}
\hline Posttest & $\mathrm{N}$ & Mean & Std. dev & Df & t-cal & P \\
\hline Computer Aided Instruction & 73 & 34.54 & 4.72 & 134 & 2.05 & 0.00 \\
Lectures & 63 & 23.45 & 4.02 & & & \\
\hline
\end{tabular}

\section{Discussion of Findings}

The result of research question one and testing of its null hypothesis revealed that students have equal entry background in business ethnics. No significant difference exists in the mean scores of control and experimental groups. The mean score of the two groups stood at 22.49 and 21.29 respectively while the $p=0.23$. The outcome of the result might be attributed to similarly instructional strategy (lectures) used in the higher institutions. The method has been criticized for not been effective in teaching students regardless of their educational level, age and cognitive development. This agreed with Adamu, Haruna and Bshir (2013), Adamu and Jibrin (2017) and Abdullahi and Jibrin (2017) who all agreed that lecturers method used in tertiary institutions has negative effective on students academic performance.

The finding of research question two which was further affirmed by research test of corresponding null hypothesis shows that no difference exist between the pretest and posttest mean performance of students taught corporate ethics using lecturers method. The mean score obtained from pretest was 22.49 while the posttest stood at 23.45 and the p-value in the test of hypothesis was 0.13 . The outcome of the study is attributed to similar instructional strategy adopted in both the pretest and posttest. The finding agrees with earlier submission of Adamu and Jubril (2012) and Adamu and Usman (2017) who opined that learning environment with a presentation from the course teacher accompanied by a lecture neither promotes learners' participation nor build the required level of reasoning for better understanding of the main concepts.

The data used to determine research question four and test of corresponding null hypothesis shows that difference exist between the pre-test and post-test mean score of students taught corporate ethics using CAI. The mean score obtained for pretest was 21.29 while the posttest stood at 34.54 . The result of test of null hypothesis shows that there was significant difference between the pretest and posttest mean score, $p=.001$. The outcome is attributed to effectiveness of CAI instructional strategy adopted. The result of the study was affirmation of Omila, (2012) who's found that females exposed to co-operative CAI performed better than their male counterparts in introductory technology since females concentrated more and were able to remedy their mistake more than the male, female can perform better with ICT concept. The findings is also in line with Rotbain, et al (2008) computer animation technology has proved to be of great use in teaching and learning of female students, especially in remediation of learning difficulties of students in business education. The result shows the mean score of 34.54 for students taught using CAI while those taught using lectures has the mean of 23.45. The test of null hypothesis revealed the p-value of .000 .

The result research question three indicated that there was difference between posttest mean performance of students taught corporate ethics using CAI and those taught using lectures method. The mean score of 34.54 for students taught using CAI while those taught using lectures has the mean of 23.45. The test of null hypothesis revealed the p-value of .000 . The finding validate the earlier result of Omila (2012) who's found that females exposed to co-operative CAI performed better than their male counterparts in introductory technology since females concentrated more and were able to remedy their mistake more than the male, female can perform better with ICT concept. The findings is also in line with Rotbain, et al (2008) computer animation technology has proved to be of great use in teaching and learning of female students, especially in remediation of learning difficulties of students in business education.

\section{Conclusion/Recommendation}

Based on the findings of this study, it was concluded CAI package used in the study has significant influence on students' academic achievement compared to the conventional method of teaching. Based on the outcome, it was recommended that Business education lecturers should incorporate the use of CAI in teaching corporate ethics to students

\section{References}

Abdullahi A. C. \& Jibrin A. G. (2017). Effect of Jigsaw-Based Instructional strategy on academic achievement of cell biology students in government secondary schools in Bauchi, Nigeria. Ife Journal of Theory and Research in Education. 18 (1) 10-18

Achuonye, K., A. (2011). Using Computer Science Class: The Interactive Effect of Gender. Journal of African Studies and Development, 3(7), 13-134.

Adamu, I. \& Jibrin, A. H. (2017). Effects of Flipped and Conventional Teaching Approaches on Performance and Retention Ability of Students in Advance Financial Accounting in Abubakar Tafawa Balewa University Bauchi, Nigeria. Journal Psikologi Malaysia. 31 (1) 12-20. 
Adamu, I. \& Jubril, A.H. (2012). Influence of Lecturers' Methodology on Performance of Accounting Students in Business Education Programme in Nigerian Universities. Journal of Education and Applied Psychology. 5 (1) $136-147$.

Adamu, I. \& Usman, M. A. (2017). Effects of Flipped and Convention Classroom Approach on Students performance in Entrepreneurial Education in Ahmadu Bello University Zaria, Kaduna state, Nigeria. International Journal of Tropical Education Issues. .

Adamu, I., Haruna J. A. \& Bshir. A. U. (2013). Effects Of Jigsaw and Lecture Based Techniques on Class Attendance, Participation and Proficiency of Undergraduate Students in Business Mathematics in Nigeria. Technical \& Vocational Education Journal. 5(1).

Akudolu, L. R. (2008) years problems Computer Assisted Language Learning as a teaching Mode for Promoting Students' Interest in French language. Technology and research journal (TERJ), 2 (1) 40-46, ESUL Press Enugu

Neekpoa A. (2007). The effect of Cognitive Apprenticeship Instructional Method on the Achievement of AutoMechanics Students in Technical College, Rivers State, Unpublished M. Ed Thesis University of Nigeria, Nsukka.

Nwokenna C. (2010). Introduction to Education Research Nigeria; Heinemann Educational Books.

Okereke, A. A. (2002) Information Technology and it is Application in Accounting Education. Book of Reading by Nigerian Association of Business Education. 3 (5), 37.

Omila, M. A. (2012). Effect of Computer Assisted Instructional Package on the Performance of Senior Secondary School Physics Students in Ilorin Metropolis. British Journal of Science, 45

Orjika, M. O. (2-12). Effect of Computer Assisted Instruction Packages on secondary school students Achievement and interest in biology." Unpublished M.Ed. Thesis Submitted to the Department of Science Education, Nnamdi Azikiwe University, Awka, Anambra State.

Rotbain, Y. (2008). Using a Computer Amination to teach High School molecular Biology Journal of Science Educational Technology, 49-58.

Sengaa, J,. Ndiriyua, M., Osundawaa, J., Irimua, G., \& English, M. (2010). Computer aided learning to link evidence to pediatric learning and practice: a pilot in a medical school in a low income setting. Int Health, 2(3), 212-215. Doi: 10.1016/j.inhe.2010.06.002.

The Federal Republic of Nigeria (2004). National Policy on Education Lagos, NERDC Press.

Yusuf, M.O Afolabi A.O. (2010). Effects of Computer Aided Instruction (CAIP) on Secondary School Students performance in Biology. The Turkish-online journal of Educational Technology. Vol. 1 issue (1); 62-69, Retrieved on 22/6/2014 from http;//www.tojet.net/articles/918pt. 